\title{
Absorption of 2-Hydroxy-4-Methylthiobutyrate and Conversion to Methionine in Lambs
}

\author{
G. E. Lobley, ${ }^{\star 1}$ T. J. Wester, ${ }^{\star 2}$ A. G. Calder, ${ }^{\star}$ D. S. Parker, $\dagger$ J. J. Dibner, $\dagger$ \\ and M. Vázquez-Añón† \\ *Rowett Research Institute, Bucksburn, Aberdeen, AB21 9SB, UK \\ †Novus International Inc., St. Louis, MO 63304
}

\begin{abstract}
Absorption and metabolism of the Met hydroxy analog 2-hydroxy-4-methylthiobutyrate (HMTBA) was examined using stable isotopes. In the first trial, DL[1${ }^{13} \mathrm{C}$ ]HMTBA was infused for $6 \mathrm{~h}(7.4 \mu \mathrm{mol} / \mathrm{min})$ into the abomasum, and $\left[{ }^{2} \mathrm{H}_{3}\right]$ Met was infused into the mesenteric vein, of 4 lambs prepared with vascular catheters across the splanchnic bed. Daily, lambs were offered $35 \mathrm{~g}$ of a mixed forage-concentrate feed $/ \mathrm{kg}$. Recovery of HMTBA at the portal vein was $87 \%$, and of this, $63 \%$ bypassed the liver. In contrast, hepatic extraction of Met equaled or exceeded net absorption. Only small quantities of Met synthesized from HMTBA were exported from either the digestive tract or liver, but there was substantial and significant input from posthepatic tissues. In a second experiment, 3 of the lambs were killed following 4-h infusions of DL $\left[1-{ }^{13} \mathrm{C}\right] \mathrm{HMTBA}$ and $\left[{ }^{2} \mathrm{H}_{3}\right]$ Met with enrichments monitored in 15 tissues. Only kidney showed $\left[1-{ }^{13} \mathrm{C}\right]$ Met enrichment higher than plasma, which suggests that it must be a primary source of plasma Met derived from HMTBA. Based on comparison of plasma and intracellular [1$\left.{ }^{13} \mathrm{C}\right]:\left[{ }^{2} \mathrm{H}_{3}\right]$ Met enrichments, all tissues synthesized Met from HMTBA but to significantly different extents. The lowest values were for muscle, skin, brain, and lung; intermediate conversions occurred in rumen, omasum, abomasum, duodenum, jejunum, ileum, and cecum; and the greatest synthesis, equivalent to 22 to $24 \%$ of Met entry into cells, was observed for liver and kidney. Therefore, although liver and kidney both converted HMTBA to Met, it was retained by the former and exported by the latter. Under these experimental conditions, synthesis of Met from HMTBA completely eliminated use of dietary Met.
\end{abstract}

Received April 29, 2005.

Accepted November 2, 2005.

${ }^{1}$ Corresponding author: gel@rri.sari.ac.uk

${ }^{2}$ Current address: Institute of Food, Nutrition and Human Health, Massey University, Private Bag 11 222, Palmerston North, New Zealand.
Key words: sheep, 2-hydroxy-4-methylthiobutyrate, methionine, absorption

\section{INTRODUCTION}

In both poultry (Waldroup et al., 1981) and pigs (Knight et al., 1998), the Met hydroxy analog DL-2-hydroxy-4-methylthiobutyrate (HMTBA), given as a liquid commercial supplement (Alimet, Novus International Inc., St. Louis, MO), has proved an effective source of supplemental dietary Met. Although conversion of the hydroxy-analog first to oxo-Met and then to L-Met can occur in a range of tissues in ruminants (McCollum et al., 2000) and nonruminants (Dibner and Knight, 1984), most attention has focused on the liver. This is because liver contains high activities of the 2 enzymes that metabolize the $\mathrm{D}$ and $\mathrm{L}$ isomers and also removes most of absorbed HMTBA in anesthetized chickens (Wang et al., 2001). In conscious lambs, however, the majority of absorbed HMTBA bypassed the liver, and net hepatic removal of Met exceeded dietary absorption (Wester et al., 2006). Despite this, HMTBA provision increased markedly the flux of plasma Met, implicating nonhepatic tissues as major sites of synthesis of Met from HMTBA. Nonetheless, increases in plasma Met concentrations following HMTBA provision are usually less than those for equimolar supplementation with DL-Met (Vazquez-Anon et al., 2001). Data from DL-Met supplementation are complicated by the accumulation of D-isomer in the plasma (Vazquez-Anon et al., 2001); however, there are clearly marked differences among ruminant tissues between the metabolism and use of HMTBA compared with Met.

Some of these issues are addressed in the current study, as the metabolism of HMTBA in ruminants is examined using stable isotope approaches. Three questions were asked. First, to what extent is the small intestine involved in the conversion of HMTBA to Met? Second, which other ovine tissues convert HMTBA to Met? Third, which tissues contribute to the extraplasma Met flux observed following HMTBA supplementation? Elements of this study have been reported previously (Wester et al., 2000). 


\section{MATERIALS AND METHODS}

Four Suffolk crossbred lambs $(\mathrm{BW}=57.2 \mathrm{~kg}, \mathrm{SE}=$ 3.5) were prepared with silicone rubber catheters in the aorta, mesenteric, portal, and hepatic veins as described previously (Lobley et al., 1995). A polyvinyl chloride catheter was also inserted into the abomasum. After 2 wk of recovery from surgery, the animals were adjusted to metabolism crates and offered a forageconcentrate diet (50\% hay, 30\% barley, $10 \%$ molasses, $9 \%$ fish meal, and $1 \%$ vitamin and mineral mix; as-fed basis) supplied at $35 \mathrm{~g} / \mathrm{kg}$ of BW offered in 24 hourly portions daily. These experiments were approved by the Ethical Review Committee of the Rowett Research Institute and conformed to U.K. legislation of the Animals (Scientific Procedures) Act 1986.

\section{Experiment 1}

Animals were continuously infused into the abomasum for $18 \mathrm{~h}$ with Alimet (as $7.4 \mu \mathrm{mol}$ of HMTBA/min; Alimet chemical purity $=88 \%$ HMTBA). The Alimet was then replaced with $\left[1-{ }^{13} \mathrm{C}\right]$ Alimet (99 atom percent, $88 \%$ chemical purity; synthesized by Novus International Inc.) for $6 \mathrm{~h}$. During this period, a solution of L[methyl- ${ }^{2} \mathrm{H}_{3}$ ] Met (7.3 $\mathrm{mM}, 99$ mole percent; Isotec Inc., Miamisburg, $\mathrm{OH}$ ) in physiological saline [154 $\mathrm{mM} \mathrm{NaCl}$ containing $700 \mathrm{IU}$ of heparin/g (Leo Laboratories Ltd., Princes Risborough, UK)] was infused into the mesenteric vein at $15 \mathrm{~g} / \mathrm{h}$. In addition, a solution of $0.267 \mathrm{M}$ $p$-aminohippurate in $0.05 M$ sodium phosphate buffer (pH 7.4) was also infused into the mesenteric vein at the rate of $15 \mathrm{~g} / \mathrm{h}$. For the last $2 \mathrm{~h}$ of this infusion, $4 \times 30$ min integrated samples were removed from the aorta, portal vein, and hepatic vein (each $6 \mathrm{~g} / 30 \mathrm{~min}$ ) by peristaltic pump and collected over ice (Lobley et al., 1995).

\section{Experiment 2}

Five to 6 wk later, 3 of the lambs used previously in Experiment 1 were again infused for $18 \mathrm{~h}$ into the abomasum with unlabelled Alimet $(7.4 \mu \mathrm{mol}$ of HMTBA/min). This was then replaced by $\left[1-{ }^{13} \mathrm{C}\right]$ Alimet $(7.4 \mu \mathrm{mol} / \mathrm{min})$ for $4 \mathrm{~h}$ while a solution of $\mathrm{L}$-[methyl$\left.{ }^{2} \mathrm{H}_{3}\right]$ Met $(7.3 \mathrm{mM})$ in physiological saline (154 $\mathrm{mM}$ $\mathrm{NaCl}$ ) was infused into the jugular vein at a rate of 15 $\mathrm{g} / \mathrm{h}$ through a temporary, polyvinylchloride catheter. During the last hour of infusion, blood $(6 \mathrm{~mL})$ was sampled at 20-min intervals from the aorta, mesenteric, and hepatic veins. At the end of infusion, the lambs were killed immediately by pentobarbitone overdose, and tissue samples from the rumen, omasum, abomasum, duodenum, jejunum, ileum, cecum, colon, liver, kidney, muscle, skin, lung, and brain were removed rapidly and frozen in liquid nitrogen. All samples were stored at $-80^{\circ} \mathrm{C}$ until preparation for analysis.

\section{Chemical Analyses}

Tissue samples were ground in a freezer mill (Spex 6700, Glen Creston, Stanmore, UK) under liquid nitrogen and stored at $-80^{\circ} \mathrm{C}$ until analysis. Plasma was prepared from blood by centrifugation at $1,000 \times g$ for $15 \mathrm{~min}$ at $4^{\circ} \mathrm{C}$. Plasma flow rate was calculated from downstream dilution of $p$-aminohippurate by a gravimetric procedure (Lobley et al., 1995). To a known weight (approximately $1 \mathrm{~g}$ ) of plasma, or ground tissue, was added $0.3 \mathrm{~g}$ of a mixture of $0.1 \mathrm{mM}\left[1-{ }^{13} \mathrm{C}\right]$ Met (99 mole percent; Isotec Inc.) and $0.1 \mathrm{mM}$ sodium [1${ }^{13}$ C]HMTBA (Wester et al., 2006). This was used to determine concentrations of Met and HMTBA in plasma and tissues by the isotope dilution technique (Calder et al., 1999) as described previously (Wester et al., 2006). Other portions of plasma or ground tissue were used to determine enrichments of $\left[{ }^{2} \mathrm{H}_{3}\right]$ Met, [1$\left.{ }^{13} \mathrm{C}\right]$ Met, and $\left[1-{ }^{13} \mathrm{C}\right] \mathrm{HMTBA}$ as described previously (Wester et al., 2006).

The proportion of HMTBA present in biological samples as D- and L-isomers was determined by chiral column, gas chromatography-mass spectrometry. To 0.9 $\mathrm{mL}$ of plasma was added $200 \mu \mathrm{L}$ of $38 \%$ sulfosalicylic acid; the sample was mixed and centrifuged at 10,000 $\times g$ for $5 \mathrm{~min}$. The supernatant was extracted twice with $2 \mathrm{~mL}$ of ethyl acetate, and the pooled organic layer was centrifuged at $5,000 \times g$ for 5 min prior to drying over sodium sulfate for $10 \mathrm{~min}$ and evaporation to dryness at $40^{\circ} \mathrm{C}$ under nitrogen. To the dry residue was added $40 \mu \mathrm{L}$ of $\mathrm{CH}_{3} \mathrm{CN}$ :pyridine:1,3-dichlortetrafluroacetone (30:5:5) and the dioxolanone derivatives formed by standing at room temperature for $10 \mathrm{~min}$ (Midgley et al., 1990). The derivatized D- and L-enantiomers of HMTBA were separated on a $25-\mathrm{m} \times 0.25-\mathrm{mm} \times 0.25$ mm Chirasil-Dex capillary column (Chrompack, Middleburg, The Netherlands) using a temperature program based on $125^{\circ} \mathrm{C}$ for 10 min then $30^{\circ} \mathrm{C}$ per min to $200^{\circ} \mathrm{C}$ for $3 \mathrm{~min}$. Injections $(1 \mu \mathrm{L})$ were made with a 50:1 split with the gas chromatography-mass spectrometry in the electron impact mode under selective ion monitoring conditions and the ion at $\mathrm{m} / \mathrm{z} 330$ monitored for HMTBA isomers.

\section{Calculations}

Net portal-drained viscera (PDV) absorption and splanchnic extraction of Met and HMTBA were calculated as described previously (Wester et al., 2006):

$$
\text { net portal transfers }(\mu \mathrm{mol} / \mathrm{min})=([\mathrm{P}]-[\mathrm{A}]) \times \mathrm{PPF}
$$


and

net splanchnic transfers $(\mu \mathrm{mol} / \mathrm{min})=([\mathrm{H}]-[\mathrm{A}]) \times \mathrm{HPF}$

where $[\mathrm{A}],[\mathrm{P}]$, and $[\mathrm{H}]$ represent concentrations $(\mathrm{g} / \mathrm{kg})$ in arterial, portal vein, and hepatic vein plasma, respectively, and PPF and HPF represent plasma gravimetric flows $(\mathrm{kg} / \mathrm{min})$ in the portal and hepatic veins, respectively. Positive numbers represent net appearance across a tissue bed, and negative values indicate net uptake. Liver transfers were obtained as the difference between splanchnic and portal transfers.

Isotope transfers were calculated similarly (Lobley et al., 1995), i.e.,

net portal transfers $(\mu \mathrm{mol} / \mathrm{min})=$

$$
([\mathrm{P} \times \mathrm{Ep}]-[\mathrm{A} \times \mathrm{Ea}]) \times \mathrm{PPF}
$$

and

net splanchnic transfers $(\mu \mathrm{mol} / \mathrm{min})=$

$$
([\mathrm{H} \times \mathrm{Eh}]-[\mathrm{A} \times \mathrm{Ea}]) \times \mathrm{HPF}
$$

where Ea, Ep, and Eh represent the enrichments (mole percent excess; mpe) of HMTBA or Met in the arterial, portal, and hepatic plasma, respectively. Calculation of gross Met fluxes were obtained by dividing isotope transfers by the enrichment in the venous drainage (portal vein for PDV; hepatic vein for the liver and total splanchnic tissues).

The fraction of Met derived from HMTBA was calculated from the enrichment ratios of $\left[1-{ }^{13} \mathrm{C}\right]$ Met:[1${ }^{13}$ C]HMTBA. Net release by either the PDV or liver of Met synthesized from HMTBA was detected as an increase in the $\left[1-{ }^{13} \mathrm{C}\right]$ Met: $\left[{ }^{2} \mathrm{H}_{3}\right]$ Met in the outflow plasma compared with the inflow plasma. Although some changes in ratio might occur through replacement of the $\left[{ }^{2} \mathrm{H}_{3}\right]$ methyl group by an unlabeled methyl group during the Met cycle (conversion of Met to homocysteine and then resynthesis to Met), in most ovine tissues, this activity is low or nonexistent (Lobley et al., 1996).

For Experiment 2, estimates were made of the fraction of Met in the tissues that arose by intracellular synthesis from HMTBA. Two routes contribute to label Met within the cell: synthesis from HMTBA in other organs, transport to the tissue, and uptake as part of normal Met metabolism (i) and synthesis from HMTBA in situ (ii). The proportion of (ii)/[(i) + (ii)], termed $x$, is obtained from the equation

$$
1-x=\mathrm{Rp} / \mathrm{Rt}
$$

where $\mathrm{R}$ is the $\left[1-{ }^{13} \mathrm{C}\right]:\left[{ }^{2} \mathrm{H}_{3}\right]$ Met in either arterial plasma (p) or the tissue (t) free pool. These proportions of la-

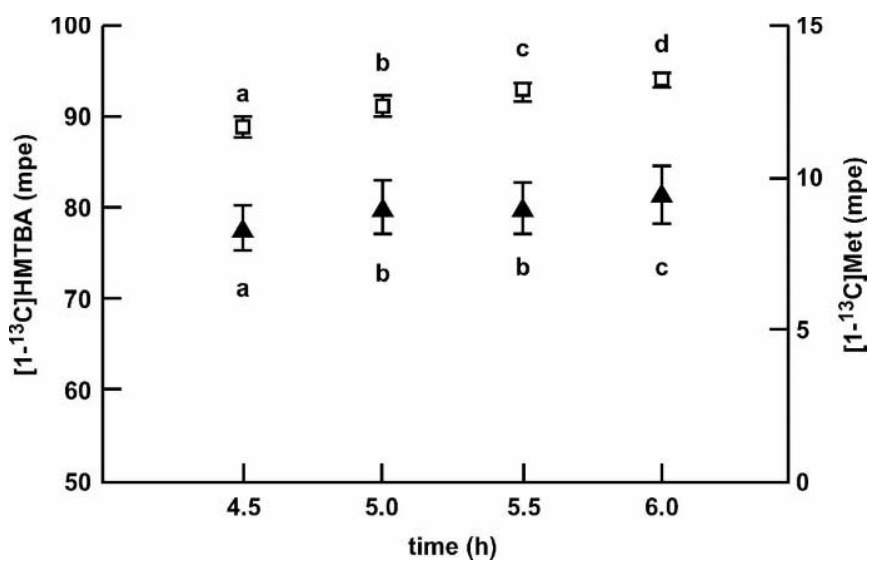

Figure 1. Change in enrichment (mole percent excess; mpe) of arterial $\left[1-{ }^{13} \mathrm{C}\right] 2$-hydroxy-4-methylthiobutanoic acid ( $\square$; HMTBA) and $\left[1-{ }^{13} \mathrm{C}\right] \mathrm{Met}(\mathbf{\Delta})$ over the last $2 \mathrm{~h}$ of a $6 \mathrm{~h}$-infusion of $\left[1-{ }^{13} \mathrm{C}\right] \mathrm{HMTBA}$ $(7.4 \mu \mathrm{mol} / \mathrm{min})$ into the abomasum. Values are means of 4 lambs with SEM values. Data points of similar symbol but different letter within each labeled metabolite are significantly different $(P<0.001)$ based on lambs as a random effect and time as a fixed effect.

beled Met inflow from synthesis in situ and inward transport are then adjusted to relative mass flows, i.e., by dividing by the enrichments of the arterial [1$\left.{ }^{13} \mathrm{C}\right]$ Met (for inward transport) and $\left[1-{ }^{13} \mathrm{C}\right] \mathrm{HMTBA}$ (for synthesis in situ).

\section{Statistics}

Data were analyzed using GenStat for Windows, version 6, release 6.1 (Lawes Agricultural Trust, Rothamsted, Herts, UK). To compare data between blood vessels, ANOVA was applied with animal as the random term and vessel as the fixed effect (Tables 5 and 6). For comparison of enrichments over time, a repeated measures ANOVA was applied with random terms for animal and time sequence within animal; time was a fixed effect (Figure 1). For comparisons of enrichments across time and blood vessels, a repeated measures ANOVA was used with random terms for sheep, time, vessels, and their interactions within sheep and with fixed effects for time, vessel, and their interaction (Tables 3 and 4). Treatment differences $(P<0.05)$ were assessed by use of Fisher's protected least significant difference test.

\section{RESULTS}

All animals recovered well from surgery, and all catheters remained patent throughout Experiment 1. By the start of Experiment 2, however, one animal was removed from the study because of failure of an arterial catheter. There were no intake refusals at any stage of the study. 
Table 1. Mass transfers of 2-hydroxy-4-methylthiobutanoic acid (HMTBA) across the splanchnic tissues during infusion of [1$\left.{ }^{13} \mathrm{C}\right]$ HMTBA $(7.4 \mu \mathrm{mol} / \mathrm{min})$ into the abomasum and [methyl $\left.-{ }^{2} \mathrm{H}_{3}\right] \mathrm{Met}$ $(1.85 \mu \mathrm{mol} / \mathrm{min})$ into the mesenteric vein of lambs

\begin{tabular}{lrc}
\hline Item $^{1}$ & Mean $^{2}$ & SEM \\
\hline Plasma flows (g/min) & & \\
PV & 1,751 & 121 \\
HV & 1,872 & 167 \\
HA & 121 & 49 \\
HMTBA concentrations $(\mu M)$ & & \\
A & 19.6 & 3.5 \\
PV & 22.8 & 3.7 \\
HV & 21.5 & 3.8 \\
HMTBA transfers ( $\mu$ mol/min) & & \\
PV flow & 39.1 & 5.4 \\
HA flow & 1.9 & 0.7 \\
HV flow & 39.1 & 5.6 \\
Net PDV appearance & 5.5 & 0.1 \\
Net SPL appearance & 3.5 & 0.4 \\
Percentage of net PDV/infused & 86.6 & 1.93 \\
Percentage of LR/net PDV & -36.8 & 7.3 \\
Percentage of LR/total liver inflow & -5.7 & 2.0 \\
\hline
\end{tabular}

${ }^{1} \mathrm{PV}=$ portal vein $\mathrm{HV}=$ hepatic vein; $\mathrm{HA}=$ hepatic artery; $\mathrm{A}=$ aorta; PDV = portal-drained viscera; SPL = splanchnic; $\mathrm{LR}=$ liver removal.

${ }^{2}$ Values from 4 lambs based on the means of $4 \times 30$-min integrated samples taken during the last $2 \mathrm{~h}$ of a 6 -h infusion.

\section{Experiment 1}

Mass transfers of HMTBA and Met are reported in Tables 1 and 2. Portal vein flow contributed 93\% (range $=90$ to $98 \%$ ) to total plasma flow at the liver. On average, $87 \%$ (range $=83$ to $91 \%$ ) of infused HMTBA was recovered at the portal vein. Of this, $37 \%$ was then removed during passage across the liver. Thus, the ma-

Table 2. Mass transfers of Met across the splanchnic tissues during infusion of $\left[1-{ }^{13} \mathrm{C}\right] 2$-hydroxy-4-methylthiobutanoic acid $(7.4 \mu \mathrm{mol} /$ min) and [methyl- $\left.{ }^{2} \mathrm{H}_{3}\right]$ Met $(1.85 \mu \mathrm{mol} / \mathrm{min})$ into the mesenteric vein into the abomasum of lambs

\begin{tabular}{lrr}
\hline Item $^{1}$ & Mean $^{2}$ & SEM \\
\hline Met concentrations $(\mu M)$ & & \\
A & 35.0 & 5.3 \\
PV & 41.3 & 5.6 \\
HV & 33.6 & 6.0 \\
Met transfers $(\mu \mathrm{mol} / \mathrm{min})$ & & \\
PV flow & 73.5 & 13.5 \\
HA flow & 3.7 & 1.4 \\
HV flow & 64.2 & 14.0 \\
Net PDV appearance & 11.2 & 1.7 \\
Net SPL appearance & -1.8 & 2.7 \\
Net LR & -13.0 & 1.3 \\
Percentage of LR/total liver inflow & -18.9 & 4.5 \\
\hline
\end{tabular}

${ }^{1} \mathrm{~A}=$ aorta; $\mathrm{PV}=$ portal vein $\mathrm{HV}=$ hepatic vein $\mathrm{HA}=$ hepatic artery; PDV = portal-drained viscera; $\mathrm{SPL}=$ splanchnic; $\mathrm{LR}=$ liver removal.

${ }^{2}$ Values from 4 lambs based on the means of $4 \times 30$-min integrated samples taken during the last $2 \mathrm{~h}$ of a 6 -h infusion. jority of the absorbed HMTBA was available to peripheral tissues. Indeed, when total HMTBA flow to the liver was considered (to include that available from recirculation), $<6 \%$ was extracted on each pass. In contrast, all of the net absorbed Met $(11 \mu \mathrm{mol} / \mathrm{min})$ was removed by the liver, and for 2 of the lambs, hepatic extraction of Met exceeded absorption. For these lambs, this indicated that some Met of postliver origin was extracted from posthepatic sources and resulted in an apparent negative availability of Met $(-2 \mu \mathrm{mol} / \mathrm{min})$ beyond the liver to peripheral tissues. In support of the higher net removal of Met by the liver compared with HMTBA, the fractional removal of total Met inflow to the liver was, at $18 \%$, also substantially greater $(P<$ 0.001) than that observed for HMTBA.

In all blood vessels, enrichments of $\left[1-{ }^{13} \mathrm{C}\right] \mathrm{HMTBA}$ were lower than the 99 mpe of the infused material (Table 3). This was probably due to the presence of natural abundance HMTBA infused for $18 \mathrm{~h}$ prior to label administration. This is supported by the observation that with time of sampling, the $\left[1-{ }^{13} \mathrm{C}\right] \mathrm{HMTBA}$ enrichment in all vessels increased $(P<0.001)$, which was further exemplified for arterial enrichments as shown in Figure 1. This explanation is compatible with the biological half-life of 70 min for HMTBA in both cattle and sheep (Lobley et al., 2001). Similar responses with time $(P=0.004)$ were also observed for the enrichments of the product, $\left[1-{ }^{13} \mathrm{C}\right]$ Met, across all vessels (see also arterial values in Figure 1). In contrast, there was no significant response with time $(P=0.353)$ for the enrichment of the infused $\left[{ }^{2} \mathrm{H}_{3}\right]$ Met.

Across sample sites, there were small, but significant, differences $(P<0.001)$ in enrichment between the blood vessels for $\left[1-{ }^{13} \mathrm{C}\right] \mathrm{HMTBA}$; values for the artery were lower than those for the portal and hepatic veins (Table 3 ). These results probably reflect label dilution inversely related to the closeness to the site of absorption of the [1-13C]HMTBA infused into the abomasum. A similar pattern was also observed $(P=0.035)$ for $\left[{ }^{2} \mathrm{H}_{3}\right]$ Met enrichments, and this would again reflect closeness to the site of infusion (mesenteric vein). In contrast, although there were significant differences $(P$ $<0.001$ ) between the vessels for the enrichments for [1$\left.{ }^{13} \mathrm{C}\right]$ Met, the order was different: aorta $>$ hepatic vein $\geq$ portal vein $(P=0.043$ for comparison of the latter 2 vessels).

The proportion of Met in arterial plasma derived from HMTBA was, on average, $9.7 \%$ (range $=8.1$ to $11.3 \%$ ). The ratio of $\left[1-{ }^{13} \mathrm{C}\right]:\left[{ }^{2} \mathrm{H}_{3}\right]$ Met enrichments was also highest in arterial plasma and lowest in the portal samples (site difference, $P=0.001$ ).

\section{Experiment 2}

Plasma enrichments of both $\left[1-{ }^{13} \mathrm{C}\right]$ and $\left[{ }^{2} \mathrm{H}_{3}\right]$ Met were stable over the $1 \mathrm{~h}$ of sampling at the end of the 
Table 3. Enrichment (mole percent excess) of $\left[1-{ }^{13} \mathrm{C}\right] 2$-hydroxy-4-methylthiobutanoic acid (HMTBA) and $\left[1-{ }^{13} \mathrm{C}\right]$ and $\left[{ }^{2} \mathrm{H}_{3}\right]$ Met in plasma from blood vessels across splanchnic tissues during infusion of $\left[1-{ }^{13} \mathrm{C}\right] \mathrm{HMTBA}$ $(7.4 \mu \mathrm{mol} / \mathrm{min})$ into the abomasum and $\left[\mathrm{methyl}-{ }^{2} \mathrm{H}_{3}\right] \mathrm{Met}(1.85 \mu \mathrm{mol} / \mathrm{min})$ into the mesenteric vein of lambs

\begin{tabular}{lrrrrrr}
\hline Item & $\mathrm{A}^{1}$ & PV & HV & SEM $^{2}$ & $P$ vessel $^{2}$ & $P$ time $^{2}$ \\
\hline$\left[1-{ }^{13} \mathrm{C}\right]$ HMTBA & $91.63^{\mathrm{a}}$ & $92.44^{\mathrm{b}}$ & $92.20^{\mathrm{b}}$ & 0.069 & $<0.001$ & $<0.001$ \\
{$\left[1{ }^{13} \mathrm{C}\right]$ Met } & $8.93^{\mathrm{a}}$ & $7.37^{\mathrm{b}}$ & $7.61^{\mathrm{b}}$ & 0.121 & $<0.001$ & 0.004 \\
{$\left[{ }^{2} \mathrm{H}_{3}\right]$ Met } & $4.08^{\mathrm{a}}$ & $4.78^{\mathrm{b}}$ & $4.45^{\mathrm{ab}}$ & 0.143 & 0.035 & 0.353 \\
{$\left[1{ }^{13} \mathrm{C}\right]:\left[{ }^{2} \mathrm{H}_{3}\right]$ Met } & $2.19^{\mathrm{a}}$ & $1.55^{\mathrm{b}}$ & $1.74^{\mathrm{b}}$ & 0.067 & 0.001 & 0.926 \\
\hline
\end{tabular}

${ }^{\mathrm{a}, \mathrm{b}}$ Values within rows with unlike superscripts differ between vessels $(P<0.05 ; 6$ residual $\mathrm{df})$.

${ }^{1} \mathrm{~A}=$ arterial; $\mathrm{PV}=$ portal vein; $\mathrm{HV}=$ hepatic vein.

${ }^{2}$ Values from 4 lambs based on 4 integrated samples taken from each vessel at 30 -min intervals during the last $2 \mathrm{~h}$ of a 6 -h infusion. The ANOVA used animal, vessel, time, and their interaction as random effects. Treatment (fixed effect) was for vessel, time, and their interaction (18 residual df). The SEM values are given for the effect of vessel.

infusion (differences between time points, $P>0.05$; data not shown). There were differences between vessels in enrichment of both $\left[1-{ }^{13} \mathrm{C}\right]$ and $\left[{ }^{2} \mathrm{H}_{3}\right]$ Met tracers $(P=$ 0.017 and $P=0.003$, respectively; Table 4 ), arterial > hepatic vein $\geq$ mesenteric vein. The lower enrichments in the splanchnic vessels probably reflect dilution by absorption of natural abundance Met and release from tissue protein degradation. There was an increase $(P=$ $0.022)$ in the $\left[1-{ }^{13} \mathrm{C}\right]:\left[{ }^{2} \mathrm{H}_{3}\right]$ Met enrichment between arterial and mesenteric plasma, indicative of synthesis and release of $\left[1-{ }^{13} \mathrm{C}\right]$ Met from $\left[1-{ }^{13} \mathrm{C}\right]$ HMTBA within the tissues drained by the mesenteric vein. Without plasma Met flows, absolute quantification of this latter input is not possible, but based on the change in ratio and relative enrichments of $\left[1-{ }^{13} \mathrm{C}\right]$ Met in the arterial plasma (approximately $5 \mathrm{mpe}$ ) and the precursor [1${ }^{13}$ C]HMTBA (95 mpe), approximately $1 \%$ of the total free Met flowing in the mesenteric vein was synthesized from HMTBA within the mesenteric drained tissues.

Data on the proportions of the $\mathrm{D}$ and $\mathrm{L}$ isomers of HMBTA in various blood vessels and tissues are pre-

Table 4. Enrichments (mole percent excess) of $\left[1-{ }^{13} \mathrm{C}\right]$ and $\left[{ }^{2} \mathrm{H}_{3}\right] \mathrm{Met}$ in plasma from the aorta, mesenteric, and hepatic veins of 3 lambs infused with $\left[1-{ }^{13} \mathrm{C}\right] 2$-hydroxy-4-methylthiobutanoic acid $(7.4 \mu \mathrm{mol} /$ $\mathrm{min})$ into abomasum and [methyl- $\left.{ }^{2} \mathrm{H}_{3}\right] \mathrm{Met}(1.85 \mu \mathrm{mol} / \mathrm{mm})$ into jugular vein for $4 \mathrm{~h}$

\begin{tabular}{|c|c|c|c|}
\hline Item & {$\left[1-{ }^{13} \mathrm{C}\right] \mathrm{Met}$} & {$\left[{ }^{2} \mathrm{H}_{3}\right] \mathrm{Met}$} & {$\left[1-{ }^{13} \mathrm{C}\right]:\left[{ }^{2} \mathrm{H}_{3}\right]$} \\
\hline Aorta & $7.76^{\mathrm{a}}$ & $4.84^{\mathrm{a}}$ & $1.63^{\mathrm{a}}$ \\
\hline Mesenteric vein & $5.80^{\mathrm{b}}$ & $2.92^{\mathrm{b}}$ & $1.99^{\mathrm{b}}$ \\
\hline Hepatic vein & $6.73^{\mathrm{ab}}$ & $3.52^{\mathrm{b}}$ & $1.91^{\mathrm{b}}$ \\
\hline SEM & 0.126 & 0.163 & 0.071 \\
\hline$P$ vessel $^{1}$ & 0.017 & 0.003 & 0.047 \\
\hline$P$ time $^{1}$ & 0.016 & 0.095 & 0.102 \\
\hline
\end{tabular}

${ }^{\mathrm{a}, \mathrm{b}}$ Values in columns with unlike superscripts are different for effect of vessel $(P<0.05 ; 4$ residual $\mathrm{df})$.

${ }^{1}$ Values for 3 lambs based on 4 samples taken from each vessel at 20-min intervals during the last $1 \mathrm{~h}$ of a 4 -h infusion. The ANOVA used animal, vessel, time, and their interaction as random effects. Treatment (fixed effect) was for vessel, time, and their interaction (16 residual df). The SEM values are given for effect of vessel. sented in Table 5. Although the infused HMTBA, whether of natural abundance or ${ }^{13} \mathrm{C}$ origin, had proportions of D:L isomer of 0.49:0.51 (data not shown), the

Table 5. Tissue 2-hydroxy-4-methylthiobutanoic acid (HMTBA) concentrations and proportion of $\mathrm{D}$ and $\mathrm{L}$ isomers following a 4-h infusion into the abomasum of $\left[1-{ }^{13} \mathrm{C}\right] \mathrm{HMTBA}(7.4 \mu \mathrm{mol} / \mathrm{min})$ and $\left[{ }^{2} \mathrm{H}_{3}\right] \mathrm{Met}$ $(1.85 \mu \mathrm{mol} / \mathrm{min})$ into the jugular vein of 3 lambs

\begin{tabular}{lcl}
\hline & $\begin{array}{l}\text { HMTBA } \\
\text { concentration, } \\
\mu M^{1}\end{array}$ & \\
& & D:L HMTBA ${ }^{2}$ \\
Plasma & & \\
Arterial & & $14.2: 85.8^{\mathrm{a}, \mathrm{x}}$ \\
Mesenteric & & $19.9: 80.1^{\mathrm{b}}$ \\
Hepatic & & $16.8: 83.2^{\mathrm{c}}$ \\
SEM & & 0.39 \\
Tissue & & \\
Rumen & $6.4^{\mathrm{y}}$ & $14: 86^{\mathrm{x}}$ \\
Omasum & $4.5^{\mathrm{y}}$ & $14: 86^{\mathrm{x}}$ \\
Abomasum & $58.5^{\mathrm{x}}$ & $43: 57^{\mathrm{y}}$ \\
Duodenum & $35.9^{\mathrm{x}}$ & $39: 61^{\mathrm{y}}$ \\
Jejunum & $62.3^{\mathrm{x}}$ & $48: 52^{\mathrm{y}}$ \\
Ileum & $14.4^{\mathrm{y}}$ & \\
Cecum & $6.1^{\mathrm{y}}$ & \\
Colon & $4.3^{\mathrm{y}}$ & $11: 89^{\mathrm{x}}$ \\
Liver & $7.9^{\mathrm{y}}$ & $14: 86^{\mathrm{x}}$ \\
Lung & $2.2^{\mathrm{y}}$ & \\
Brain & $1.8^{\mathrm{y}}$ & \\
Skin & $2.2^{\mathrm{y}}$ & \\
Muscle & $2.6^{\mathrm{y}}$ & $14: 86^{\mathrm{x}}$ \\
Bone marrow & $0.2^{\mathrm{y}}$ & 1.61 \\
Kidney & $16.3^{\mathrm{y}}$ & $<0.001$ \\
SEM & 5.85 & \\
$P$ & $<0.001$ & $\mathrm{wh}$ \\
\hline
\end{tabular}

${ }^{1}$ The ANOVA included animals as a random effect, where unlike superscripts $(\mathrm{x}, \mathrm{y})$ within the column indicate tissue values (fixed effect) that are significantly different $(P<0.05 ; 27$ residual df; one missing value).

${ }^{2}$ The ANOVA included animals treated as a random effect. For comparison of the 3 plasma samples, site was treated as the fixed effect and significant differences $(P<0.001)$ are represented by unlike superscripts $(a, b, c)$ within the column based on 4 residual df. For comparison of the tissue samples including plus arterial plasma, site was treated as the fixed effect. Significant differences $(P<0.001)$ are represented by unlike superscripts $(\mathrm{x}, \mathrm{y})$ within the column based on 16 residual $\mathrm{df}$ and assessed by Fisher's protected least significance difference test. 
Table 6. Tissue intracellular enrichments (mole percent excess; mpe) of $\left[1-{ }^{13} \mathrm{C}\right]$ and $\left[{ }^{2} \mathrm{H}_{3}\right] \mathrm{Met}$ and calculated contribution of Met synthesis in situ from 2-hydroxy-4-methylthiobutanoic acid (HMTBA) as a proportion (\%) of Met entry into cells following infusion of $\left[1-{ }^{13} \mathrm{C}\right] \mathrm{HMTBA}(7.4 \mu \mathrm{mol} / \mathrm{min})$ into the abomasum and [methyl- $\left.{ }^{2} \mathrm{H}_{3}\right]$ Met $(1.85 \mu \mathrm{mol} / \mathrm{min})$ into the jugular vein of 3 lambs

\begin{tabular}{|c|c|c|c|c|}
\hline \multirow[b]{2}{*}{ Tissue } & \multicolumn{4}{|c|}{ Enrichment (mpe) } \\
\hline & {$\left[1-{ }^{13} \mathrm{C}\right] \mathrm{Met}$} & {$\left[{ }^{2} \mathrm{H}_{3}\right] \mathrm{Met}$} & {$\left[1-{ }^{13} \mathrm{C}\right]:\left[{ }^{2} \mathrm{H}_{3}\right]$ Met } & $\begin{array}{l}\text { Percentage } \\
\text { in situ: } \\
\text { Met entry }^{1}\end{array}$ \\
\hline & & & e) & 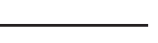 \\
\hline Plasma (arterial) & $7.76^{\mathrm{a}}$ & $4.48^{\mathrm{a}}$ & $1.63^{\mathrm{a}}$ & - \\
\hline Rumen & $5.33^{\text {bcd }}$ & $1.95^{\text {cde }}$ & $2.76^{\text {bcd }}$ & $5.9^{\mathrm{bc}}$ \\
\hline Omasum & $4.81^{\text {cdef }}$ & $1.79^{\text {defg }}$ & $2.72^{\mathrm{bcd}}$ & $5.5^{\mathrm{bc}}$ \\
\hline Abomasum & $5.12^{\text {cde }}$ & $1.72^{\text {defgh }}$ & $3.05^{\mathrm{cd}}$ & $7.2^{\mathrm{bc}}$ \\
\hline Duodenum & $2.94^{\mathrm{hi}}$ & $1.09^{\mathrm{hi}}$ & $2.81^{\text {bcd }}$ & $5.7^{\mathrm{bc}}$ \\
\hline Jejunum & $2.14^{\mathrm{i}}$ & $0.66^{\mathrm{i}}$ & $3.33^{\mathrm{d}}$ & $8.3^{\mathrm{b}}$ \\
\hline Ileum & $2.96^{\mathrm{hi}}$ & $1.46^{\mathrm{efgh}}$ & $2.07^{\mathrm{ab}}$ & $2.4^{\mathrm{bc}}$ \\
\hline Cecum & $3.98^{\text {fgh }}$ & $1.68^{\text {defgh }}$ & $2.45^{\text {abcd }}$ & $4.2^{\mathrm{bc}}$ \\
\hline Colon & $4.02^{\text {efgh }}$ & $1.81^{\text {defg }}$ & $2.16^{\mathrm{abc}}$ & $2.5^{\mathrm{bc}}$ \\
\hline Liver & $6.33^{\mathrm{b}}$ & $1.12^{\mathrm{ghi}}$ & $6.06^{\mathrm{e}}$ & $22.3^{\mathrm{a}}$ \\
\hline Lung & $4.32^{\mathrm{defg}}$ & $2.23^{\text {cd }}$ & $2.05^{\mathrm{ab}}$ & $2.4^{\mathrm{bc}}$ \\
\hline Brain & $3.70^{\text {gh }}$ & $1.86^{\text {def }}$ & $1.99^{\mathrm{ab}}$ & $1.9^{\mathrm{c}}$ \\
\hline Skin & $5.56^{\mathrm{bc}}$ & $2.93^{\mathrm{b}}$ & $1.90^{\mathrm{ab}}$ & $1.3^{\mathrm{c}}$ \\
\hline Muscle & $5.18^{\mathrm{cd}}$ & $2.55^{\mathrm{bc}}$ & $2.04^{\mathrm{ab}}$ & $2.1^{\mathrm{c}}$ \\
\hline Kidney & $7.87^{\mathrm{a}}$ & $1.22^{\text {fghi }}$ & $6.44^{\mathrm{a}}$ & $23.6^{\mathrm{a}}$ \\
\hline SEM & 0.378 & 0.237 & 0.317 & 2.09 \\
\hline$P^{2}$ & $<0.001$ & $<0.001$ & $<0.001$ & $<0.001$ \\
\hline
\end{tabular}

${ }^{\mathrm{a}-\mathrm{i}}$ Tissue values (fixed effects) within columns with unlike superscripts differ significantly $(P<0.05)$ as assessed by Fisher's protected least significance difference test.

${ }^{1}$ Calculated from $\left[1-{ }^{13} \mathrm{C}\right]:\left[{ }^{2} \mathrm{H}_{3}\right]$ Met enrichment in tissues compared with arterial plasma.

${ }^{2}$ Based on ANOVA for 3 lambs with animals as blocks (27 residual df; one missing value).

ratio in arterial plasma was $0.14: 0.86$. The proportion of D-isomer was increased $(P<0.001)$ in both the mesenteric vein (by 20\%) and hepatic vein (by 17\%), as would be expected following absorption of the racemic mixture. Of the tissues analyzed, only those immediately downstream of the site of HMTBA infusion, i.e., the abomasum, duodenum, and jejunum, had proportions of the D-isomer greater than for arterial or mesenteric vein plasma $(P<0.001)$. These tissues also had substantially higher $(P<0.001)$ concentrations of HMTBA (35 to $62 \mu M)$ than other tissues $(<17 \mu M)$, which indicates that these were major sites of absorption. Interestingly, HMTBA concentrations within tissues of the lower digestive tract, ileum, and beyond, were similar to peripheral tissues, indicative that little HMTBA was available for absorption at these sites.

For all tissues, enrichments of $\left[{ }^{2} \mathrm{H}_{3}\right]$ Met were lower than in arterial plasma $(P<0.001$; Table 6$)$, again indicative of dilution with natural abundance Met liberated from protein degradation, or absorbed from the diet (small intestine tissues only), or both. Most tissue [1$\left.{ }^{13} \mathrm{C}\right]$ Met enrichments were also lower than for arterial plasma $(P<0.001$; Table 6$)$. Only the kidney had [1$\left.{ }^{13} \mathrm{C}\right]$ Met enrichments equal to or greater than plasma (Table 6). In addition, although for all tissues the [1$\left.{ }^{13} \mathrm{C}\right]:\left[{ }^{2} \mathrm{H}_{3}\right]$ Met was greater than for arterial plasma $(P$ $<0.001$; Table 6 ), this ratio did vary between tissues.
Thus, the highest ratios were for kidney and liver $(>6$ vs. 1.63 for plasma), and the lowest were for peripheral tissues such as lung, muscle, brain, and skin (1.90 to 2.05). Tissues of the digestive tract gave intermediate ratios (2.07 to 3.33). The calculated contribution of Met synthesis in situ compared with that transported into the cell also differed $(P<0.001)$ among tissues and ranged from 2 to $24 \%$ between brain and kidney, respectively. Hepatic values (22\%) were calculated based on plasma enrichments in the portal vein, rather than the artery, as this provides most of the blood flow to the liver (Table 1).

\section{DISCUSSION}

\section{Mass Transfers}

Of the HMTBA infused into the abomasum, $87 \%$ was recovered unchanged at the portal vein. Thus, metabolism by the postabomasal digestive tract did not limit supply of HMTBA to other body tissues. Furthermore, as the fractional extraction of absorbed HMTBA by the liver was similar to previous ovine values (Wester et al., 2006), $>60 \%$ of the HMTBA infused into the abomasum reached the peripheral circulation. The fractional extractions across the ovine liver are similar to those observed for dairy cows (37\%; Lapierre et al., 2002) but 
much less than the $86 \%$ reported for chickens (Wang et al., 2001). This does not seem to reflect a restriction on hepatic uptake because fractional removals were similar over a 10-fold range of infusion in lambs (Wester et al., 2006).

This low extraction by the liver accounts for the high concentrations of HMTBA in arterial plasma (approximately one-half those observed for Met). Furthermore, as only small amounts of HMTBA are likely to be produced by endogenous metabolism of Met, plasma concentrations should reflect the amount of supplemental HMTBA that is absorbed. These relatively high concentrations in the arterial plasma mean that extensive recirculation of HMTBA to tissues occurs, and this has consequences for the proportional appearances and disappearances across the splanchnic organs. Thus, in terms of absolute rather than net flows, absorption from the digestive tract only accounted for $15 \%$ of HMTBA in the mesenteric vein (i.e., $85 \%$ was recirculated via the mesenteric artery inflow). These are similar values to those observed for Met. In contrast, hepatic extractions of total inflows were 6 and 19\% for HMTBA and Met, respectively, i.e., the liver has a greater apparent affinity for Met than HMTBA, as shown previously (Wester et al., 2006).

The greater affinity for Met is not a fixed value, however, as other findings in both anesthetized chickens (Song et al., 2001) and conscious lambs (Wester et al., 2006) have shown that Met extraction by the liver increases with HMTBA supply. Indeed, in growing lambs, net Met extraction by the liver can exceed net Met absorption, provided sufficient HMTBA is given (Wester et al., 2006), or can only allow posthepatic supply of Met that is sufficient to support 36\% of milk protein output in dairy cows (Lapierre et al., 2002). To sustain net protein anabolism under such conditions, there must be synthesis of Met by extrasplanchnic tissues.

\section{Isotope Transfers}

Failure to detect net uptake of Met across tissues does not preclude intracellular synthesis of Met. For example, intracellular synthesis from HMTBA may reduce or eliminate the need to use Met from either lumen or plasma sources. Such synthesis in vivo can only be detected by isotopic means, and in the current study, any $\left[1-{ }^{13} \mathrm{C}\right]$ Met formed must be derived from [1$\left.{ }^{13} \mathrm{C}\right]$ HMTBA. The presence of $\left[1-{ }^{13} \mathrm{C}\right]$ Met in tissues can be due to synthesis in situ or via production elsewhere followed by uptake from plasma. In practice, because Met is bidirectionally transported across ovine cell membranes (Hoskin et al., 2003), all tissues should contain $\left[1-{ }^{13} \mathrm{C}\right]$ Met. To determine whether synthesis de novo also occurs requires the inclusion of a marker of Met movements; this is provided by the $\left[{ }^{2} \mathrm{H}_{3}\right]$ Met infusion.

From this dual isotope approach, most tissues were shown to be capable of synthesizing Met from HMTBA. In the liver, such synthesis was equivalent to $20 \%$ of the Met transported into the cell from plasma, and in tissues of the digestive tract, the value was 5 to $8 \%$. Quantitatively, these are substantial values because bidirectional exchanges between tissues and plasma are considerably in excess of net uptakes. Indeed, based on rates of AA entry from plasma in the dog small intestine (Biolo et al., 1995) and protein synthesis in the sheep intestine (Lobley et al., 1994), the data in the current study would suggest that synthesis of Met by the gut tissues would increase apparent Met absorption by 10 to $15 \%$. Similar calculations for the liver [based on data from Lobley et al. (1996) and Connell et al. (1997)] would raise the Met synthesis in situ to $36 \%$ of Met extracted (approximately equal to the total amount absorbed from the diet). Despite this extensive intracellular synthesis of Met, little appears to have been exported from the splanchnic tissues. For example, from the flow of Met across the liver, the change in [1$\left.{ }^{13} \mathrm{C}\right]:\left[{ }^{2} \mathrm{H}_{3}\right]$ Met between the portal and hepatic veins, and the relative enrichments of the Met and HMTBA, efflux of synthesized Met comprises only 3\% of total hepatic transfer. A similar proportion is obtained for transfers across the digestive tract. Therefore, although the splanchnic tissues are producers of Met from HMTBA, most is retained for intracellular use and metabolism.

This means that extrasplanchnic tissues must make the major net contribution to plasma Met synthesized from HMTBA, a conclusion supported by the finding that the greatest enrichment of $\left[1-{ }^{13} \mathrm{C}\right]$ Met was in the arterial plasma, even though the $\left[1-{ }^{13} \mathrm{C}\right] \mathrm{HMTBA}$ was infused into the abomasum, i.e., presplanchnic. Main candidates for Met synthesis, based on tissue masses and the amount of enzyme present in the chicken that converts D-HMTBA to Met, the D-hydroxy acid dehydrogenase (DHADH; Dibner and Knight, 1984), would be muscle, brain, and kidney. The tracer data indicate that although both brain and muscle do synthesize Met from HMTBA, the amounts only represent $3 \%$ of Met that enters from plasma. In muscle, however, such rates of synthesis of Met would be sufficient to contribute 10 to $30 \%$ to net protein gain based on the proportion of essential AA transported into the cells that are retained in sheep (Roy et al., 1999; Hoskin et al., 2001). The tracer data indicate that a further $8 \%$ of Met that enters muscle has been synthesized from HMTBA elsewhere and transported to muscle via the plasma. This would furnish another 25 to $75 \%$ of the requirement; therefore, all of the Met needed to support muscle growth in these 
lambs can be supported from HMTBA through synthesis either directly in the muscle or from other tissues. This would also explain why all of the absorbed Met was removed by the liver, because anabolic needs were met by synthesis from HMTBA under the current conditions.

In contrast to muscle and brain, kidney is a much more active tissue in both the synthesis and export of Met. In particular, kidney was the only tissue for which the intracellular $\left[1-{ }^{13} \mathrm{C}\right]$ Met enrichment exceeded that in plasma, an important factor, as at least one tissue (the source of synthesized Met) must equal or exceed plasma enrichment (that represents the weighted average of export flows from tissues). Furthermore, kidney also had the highest $\left[1-{ }^{13} \mathrm{C}\right]:\left[{ }^{2} \mathrm{H}_{3}\right]$ Met, indicative that synthesis in situ was a substantial proportion of Met flow through renal cells. This ratio is similar to that observed for liver and fits with the observation that, in sheep, both tissues have similar activities of the 2 enzymes that convert DL-HMTBA to Met (DHADH and L- $\alpha$-hydroxy acid oxidase; McCollum et al., 2000). The difference between liver and kidney is that most of the synthesized Met is retained by hepatic cells (probably a function of unidirectional flow; Lobley et al., 1996). In contrast, kidney metabolism involves extensive interchange between plasma and intracellular AA, including Met, as part of the absorption and reabsorption process of glomerular filtration (Bovee and Segal, 1984; Tietze et al., 1992). By such processes, renal-synthesized Met from HMTBA is returned to the plasma and probably accounts for most of the increase in plasma Met flux observed previously during HMTBA infusions (Wester et al., 2006). Those changes in Met flux only accounted for $40 \%$ of the HMTBA metabolized (Wester et al., 2006), and the current observations indicate that the remainder of synthesized Met is probably retained for intracellular use, e.g., to support protein synthesis.

\section{Isomer Metabolism}

Although there was good agreement between reported enzyme activities in ovine liver and kidney (McCollum et al., 2000) and the metabolic conversion of HMTBA assessed by the ratio of $\left[1-{ }^{13} \mathrm{C}\right]:\left[{ }^{2} \mathrm{H}_{3}\right]$ Met enrichments, this did not hold for all tissues. For example, although enzyme activities in the rumen and omasum are similar to hepatic and renal values (McCollum et al., 2000), there was smaller conversion of HMTBA to Met for digestive tract tissues (Table 6). This suggests that the enzyme activity may be regulated by factors as yet unidentified.

The data also indicate differences between the rates of metabolism of the 2 isomers of HMTBA. The 2 separate enzymes that convert the $\mathrm{D}$ and $\mathrm{L}$ isomers to oxo-
Met have different distributions, both between organs and within the cell. In chickens and other species, L- $\alpha$ hydroxy acid oxidase is located within peroxisomes and predominates in kidney and liver (Robinson et al., 1962; Dibner and Knight, 1984). In contrast, DHADH is present in mitochondria and is distributed universally across tissues (Dibner and Knight, 1984) but can be more active $(+50 \%)$ as shown in chicken liver. Similarly, $\mathrm{DHADH}$ is more active (by 45 to $75 \%$ ) than L- $\alpha$-hydroxy acid oxidase in the sheep omasum, rumen, and kidney, although lower (by 20\%) in the liver (McCollum et al., 2000). This overall higher activity of DHADH is reflected in the lower proportions of the D-isomer present in the plasma. Indeed, the ratio of D:L (14:86) is much lower than the relative maximal activities of the 2 enzymes measured in vitro and may indicate that, under physiological conditions, the availability of coenzymes (flavin or nicotinamide nucleotides) and electron acceptors may constrain reaction rates. Interestingly, isomer proportions in digestive tract tissues just downstream of the site of abomasal infusion were similar to the HMTBA supplied (49:51), and the lower small intestine, forestomachs, and other body tissues had similar ratios to plasma. This may be a feature of the higher concentration of HMTBA present, the lower enzyme activity within the upper small intestine, or both. Although the plasma D:L indicate preferential metabolism of D-HMTBA, as yet there is no direct evidence whether the L-Met formed from HMTBA within the ruminant arises mainly from one isomer. This would need to be tested by examination of the metabolic fate of labeled forms of the individual isomers.

\section{CONCLUSIONS}

Although use of Met hydroxyl analogues as a source of Met in poultry and pig diets has proved a very successful husbandry practice, lower plasma Met concentrations are observed when compared with products based on DL-Met. The current data from lambs show that this is because the hydroxyl analogue is converted to Met within most body tissues and then retained to support protein gain. This preferential use by tissues of Met synthesized from HMTBA reduces use of Met absorbed from the gut, most of which is then removed and catabolized by the liver. Therefore, changes in plasma Met concentrations do not predict accurately Met availability when HMTBA is supplied. Most of any increase in plasma Met observed after HMTBA supplementation arises from metabolic conversion in the kidney and export as part of the renal filtration mechanism. There also appears to be preferential use of the D-isomer by ruminant tissues. 


\section{ACKNOWLEDGMENTS}

We acknowledge the invaluable mathematical and statistical advice given by G. Holtrop of Biomathematics and Statistics Scotland.

\section{REFERENCES}

Biolo, G., X. J. Zhang, and R. R. Wolfe. 1995. Role of membrane transport in interorgan amino acid flow between muscle and small intestine. Metabolism 44:719-724.

Bovee, K. C., and S. Segal. 1984. Renal tubule reabsorption of amino acids after lysine loading of cystinuric dogs. Metabolism 33:602-607.

Calder, A. G., K. E. Garden, S. E. Anderson, and G. E. Lobley. 1999. Quantitation of blood and plasma amino acids using isotope dilution electron impact gas chromatography/mass spectrometry with U-13C amino acids as internal standards. Rapid Commun. Mass Spectrom. 13:2080-2083.

Connell, A., A. G. Calder, S. E. Anderson, and G. E. Lobley. 1997. Hepatic protein synthesis in the sheep: Effect of intake as monitored by use of stable-isotope-labelled glycine, leucine and phenylalanine. Br. J. Nutr. 77:255-271.

Dibner, J. J., and C. D. Knight. 1984. Conversion of 2-hydroxy-4(methylthio)butanoic acid to L-methionine in the chick: A stereospecific pathway. J. Nutr. 114:1716-1723.

Hoskin, S. O., I. C. Savary-Auzeloux, A. G. Calder, G. Zuur, and G. E. Lobley. 2003. Effect of feed intake on amino acid transfers across the ovine hindquarters. Br. J. Nutr. 89:167-179.

Hoskin, S. O., I. C. Savary, G. Zuur, and G. E. Lobley. 2001. Effect of feed intake on ovine hind-limb protein metabolism based on 13 amino acids and arterio-venous techniques. Br. J. Nutr. 86:577-585.

Knight, C. D., C. A. Atwell, C. W. Wuelling, F. J. Ivey, and J. J. Dibner. 1998. The relative effectiveness of 2 -hydroxy-4-(methylthio) butanoic acid and DL-methionine in young swine. J. Anim. Sci. 73:781-787.

Lapierre, H., J. J. Dibner, M. Vazquez-Anon, D. Parker, P. Dubreuil, M. Babkine, G. Zuur, and G. E. Lobley. 2002. Use of 2-hydroxy4-[methylthio]-butanoic acid (HMB) by lactating dairy cows. J. Dairy Sci. 85(Suppl. 1):286. (Abstr.)

Lobley, G. E., A. Connell, M. A. Lomax, D. S. Brown, E. Milne, A. G. Calder, and D. A. H. Farningham. 1995. Hepatic detoxification of ammonia in the ovine liver: Possible consequences for amino acid catabolism. Br. J. Nutr. 73:667-685.

Lobley, G. E., A. Connell, E. Milne, A. M. Newman, and T. A. Ewing. 1994. Protein synthesis in splanchnic tissues of sheep offered two levels of intake. Br. J. Nutr. 71:3-12.
Lobley, G. E., H. Lapierre, D. S. Parker, J. J. Dibner, and M. VazquezAnon. 2001. HMB metabolism in ruminants. Pages 15-23 in Southwest Nutr. Manag. Conf. Proc. Univ. Arizona, Tucson.

Lobley, G. E., D. K. Revell, B. J. Bequette, D. S. Brown, and A. G. Calder. 1996. Splanchnic-bed transfers of amino acids in sheep blood and plasma, as monitored through use of a multiple U-13Clabelled amino acid mixture. Br. J. Nutr. 75:217-235.

McCollum, M. Q., M. Vasquez-Anon, J. J. Dibner, and K. E. Webb, Jr. 2000. Absorption of 2-hydroxy-4-(methylthio)butanoic acid by isolated sheep ruminal and omasal epithelia. J. Anim. Sci. 78:1078-1083.

Midgley, J. M., R. Andrew, D. G. Watson, N. MacDonald, J. L. Reid, and D. A. Williams. 1990. Dichlorotetrafluoroacetone as a derivatisation reagent in the analysis of mandelic acids in human urine. J. Chromatogr. 527:259-265.

Robinson, J. C., L. Keay, R. Molinari, and I. W. Sizer. 1962. L- $\alpha-$ Hydroxy acid oxidases of hog renal cortex. J. Biol. Chem. 237:2001-2010.

Roy, N., G. Zuur, and G. E. Lobley. 1999. Amino acid metabolism across the hind-quarters of undernourished sheep supplemented with glutamine. Page 17 in Proc. VIIIth Int. Symp. Protein Metab. Nutr., Aberdeen, UK. G. E. Lobley, A. White, and J. C. MacRae, ed. EAAP Publ. No. 96, Wageningen, The Netherlands.

Song, Z., K. Beers, J. J. Dibner, M. Vasquez-Anon, R. McNew, and W. Bottje. 2001. The hepatic extraction of plasma free amino acids and response to hepatic portal venous infusion of methionine sources in anesthetized SCWL males (Gallus domesticus). Comp. Biochem. Physiol. B Biochem. Mol. Biol. 130:237-250.

Tietze, I. N., S. S. Sorensen, H. Eiskjaer, K. Thomsen, and E. B. Pedersen. 1992. Tubular handling of amino acids after intravenous infusion of amino acids in healthy humans. Nephrol. Dial. Transplant. 7:493-500.

Vazquez-Anon, M., D. Parker, and J. J. Dibner. 2001. Differential response of free plasma D- and L-met in cows fed different rumen protected methionine sources. J. Dairy Sci. 79(Suppl. 1):284. (Abstr.)

Waldroup, P. W., C. J. Mabray, J. R. Blackman, P. J. Slagter, R. J. Short, and Z. B. Johnson. 1981. Effectiveness of the free acid of methionine hydroxy analogue as a methionine supplement in broiler diets. Poult. Sci. 60:438-443.

Wang, S., W. Bottje, Z. Song, K. Beers, M. Vazquez-Anon, and J. J. Dibner. 2001. Uptake of DL-2-hydroxy-4-(methylthio)butanoic acid (HMB) in the broiler liver in vivo. Poult. Sci. 80:1619-1624.

Wester, T. J., M. Vazquez-Anon, J. Dibner, D. S. Parker, A. G. Calder, and G. E. Lobley. 2006. Hepatic metabolism of 2-hydroxy-4-methylthiobutyrate in growing lambs. J. Dairy Sci. 89:1062-1071.

Wester, T. J., M. Vazquez-Anon, D. S. Parker, J. J. Dibner, A. G. Calder, and G. E. Lobley. 2000. Synthesis of methionine (Met) from 2-hydroxy-4-thiomethylbutryate (HMB) in growing lambs. J. Anim. Sci. 78(Suppl. 1):269. (Abstr.) 